\title{
Rearing management of rabbit males selected by high growth rate: the effect of diet and season on semen characteristics
}

\author{
Juan José PASCUAL ${ }^{\mathrm{a} *}$, Claudia GARCíA ${ }^{\mathrm{a}}$, Eugenio MARTíNEZ ${ }^{\mathrm{a}}$, \\ Eva MocÉ ${ }^{b}$ José Salvador VICENTE ${ }^{b}$ \\ a Unidad de Alimentación Animal, Departamento de Ciencia Animal, \\ Universidad Politécnica de Valencia, PO Box 22012, Valencia 46071, Spain \\ b Laboratorio de Biotecnología de la Reproducción, Departamento de Ciencia Animal, \\ Universidad Politécnica de Valencia, PO Box 22012, Valencia 46071, Spain
}

(Received 28 May 2003; accepted 15 November 2003)

\begin{abstract}
A total of sixty-six young males were used to evaluate the effect of low (L), medium (M) and high $(\mathrm{H})$ concentrations of dietary digestible energy received during the rearing seasons (autumn and spring) on the performance and main semen characteristics of males for artificial insemination selected by a high growth rate. Males reared during the spring season presented a significantly higher weight at weaning than those reared during the autumn season $(P<0.001)$, and these differences were maintained until the end of the trial. The requirements of the males were easily covered as a general rule. In the autumn group, the males were unable to intake the digestible protein recommended only during their $3 \mathrm{rd}$ month of life, especially with low concentrate diets $(P<0.05)$. $\mathrm{H}$ males showed higher semen concentration and production during the autumn season, while $\mathrm{L}$ males showed a higher semen concentration and production than $\mathrm{M}$ males during the spring season, the $\mathrm{H}$ group showed intermediate values $(P<0.001)$. Males reared during the spring season showed significantly higher values of sperm concentration $(P<0.01)$ and production $(P<0.01)$. H males presented a lower percentage of spermatozoa with cytoplasmic droplets than the $\mathrm{L}$ group $(P<0.05)$ and the lowest values for sperm abnormalities during the autumn season, while the $\mathrm{L}$ group presented higher values for percentage abnormalities, especially during the last month controlled $(P<0.05)$. As a general rule, the main motility parameters controlled were not affected by the rearing diet received nor the season. These results seem to indicate that the management of rabbit males during the growing and rearing periods seem to significantly affect their subsequent performance and semen production.
\end{abstract}

rabbit males / rearing / semen characteristics / dietary energy / season

\section{INTRODUCTION}

Rabbit males have traditionally been located between females for management reasons and consequently have usually been fed with diets for reproductive rabbit does.
However, as a consequence of artificial insemination (AI) development, specific farms for males have appeared in recent years, since the use of diets designed for specific characteristics, goals and requirements of males is now possible.

\footnotetext{
* Corresponding author: jupascu@dca.upv.es
} 
AI has been valuable for rabbit producers because males selected on the basis of desired traits of rapid and efficient growth could be used to inseminate large populations of females. However, these animals selected for high growth rate usually present a relatively low sperm count (200$600 \times 10^{6}$ ), the number of inseminations per week being reduced to 10 or 20 (the main authors advise around $16-30 \times 10^{6}$ spermatozoa per insemination). Several studies have thus been carried out to increase the number of doses and quality of the sperm produced per male, reducing the number of sperm in insemination doses [1] or improving male management [2-4].

However, sperm production and spermatozoa characteristics could also be modified by nutritional changes, and a significant number of works have been carried out to study the effects of energy [5], protein [5$8]$ and different micronutrient contents [913] of the diet on the main sperm characteristics of males destined to AI, recently reviewed by [14].

There is, however, a lack of information about the adequate nutrition of animals selected for a high growth rate, and especially during their rearing period (from weaning to the beginning of semen collection). Taking into account the high growth rate and requirements of these animals, an adequate nutrition during this period could be critical for a good reproductive performance.

The aim of the present work was to evaluate the effect of dietary concentration of digestible energy received during the rearing season on the performance and main semen characteristics of males selected for AI for high growth rate.

\section{MATERIAL AND METHODS}

\subsection{Diets}

The main ingredients and chemical analyses of experimental diets are summarised in Table I. Three pelleted diets were formulated with different digestible energy (DE) contents in order to study the effect of the dietary concentration received during the rearing time on the seminal parameters of males selected for a high growth rate. The medium diet (M) was similar to a typical commercial diet for reproductive rabbit does, with $12.3 \mathrm{MJ} \mathrm{kg}^{-1}$ dry matter (DM) and $129 \mathrm{~g}$ of digestible protein (DP) $\mathrm{kg}^{-1}$ DM. From this, a low energy diet (L), with 10.9 MJ DE kg-1 DM and $112 \mathrm{~g} \mathrm{DP} \mathrm{kg}^{-1}$ $\mathrm{DM}$, and high energy diet $(\mathrm{H})$, with $13.5 \mathrm{MJ}$ $\mathrm{DE} \mathrm{kg} \mathrm{kM}^{-1} \mathrm{DM}$ and $146 \mathrm{~g} \mathrm{DP} \mathrm{kg}^{-1} \mathrm{DM}$, were formulated by partially substituting the alfalfa hay and wheat bran content with barley grain, animal fat and soyabean meal. The DP/DE ratio was similar for the three diets (10.3, 10.4 and $10.8 \mathrm{~g}$ DP per MJ DE for $\mathrm{L}, \mathrm{M}$ and $\mathrm{H}$ diets, respectively), but acid detergent fibre (ADF) decreased as the $\mathrm{DE}$ content of the diet increased (198, 174 and $131 \mathrm{~g} \mathrm{ADF} \mathrm{kg}^{-1} \mathrm{DM}$ for $\mathrm{L}, \mathrm{M}$ and $\mathrm{H}$ diets, respectively).

The animals received a commercial diet for reproductive rabbit does (C) during the semen collection period. This diet presented a similar composition to that described for the $\mathrm{M}$ diet with $12.4 \mathrm{MJ} \mathrm{DE} \mathrm{kg}^{-1} \mathrm{DM}$ and $129 \mathrm{~g} \mathrm{DP} \mathrm{kg}^{-1}$ DM.

Apparent digestibility coefficients of energy and protein were determined using the experimental males when they were 16 weeks of age with a mean live weight of $3985 \pm 47 \mathrm{~g}$ for $\mathrm{L}, \mathrm{M}$ and $\mathrm{H}$ diets and when they were 31 weeks of age with a mean live weight of $4967 \pm 47 \mathrm{~g}$ for the $\mathrm{C}$ diet. The rabbits were housed in metabolism cages and feed and water were offered ad libitum during the experimental period. Following an adaptation period of 7 days, the faeces collection period was 4 days, as described by [15].

Pelleted diets were manufactured and analysed twice during the experimental period.

Chemical analysis of the diets and faeces were performed following the methods of the Association of Official Analytical 
Table I. Main ingredients $\left(\mathrm{g} \mathrm{kg}^{-1}\right)$ and chemical composition $\left(\mathrm{g} \mathrm{kg}^{-1}\right.$ dry matter) of the diets.

\begin{tabular}{|c|c|c|c|c|}
\hline & \multicolumn{4}{|c|}{ Diets } \\
\hline & $\mathrm{L}$ & M & $\mathrm{H}$ & $\mathrm{C}^{5}$ \\
\hline \multicolumn{5}{|l|}{ Ingredients } \\
\hline Alfalfa hay & 680 & 500 & 380 & \\
\hline Wheat bran & 150 & 100 & 50 & \\
\hline Barley grain & 99 & 250 & 320 & \\
\hline Soya-bean meal (440 g CP per kg) & 29 & 106 & 90 & \\
\hline Soya-bean grain & & & 113 & \\
\hline Animal fat ${ }^{1}$ & 5 & 10 & 15 & \\
\hline Calcium hydrogen phosphate & 10 & 15 & 11 & \\
\hline Monosodium phosphate & 15 & 9 & 12 & \\
\hline Sodium chloride & 4 & 4 & 4 & \\
\hline Lysine & 2 & 1 & & \\
\hline DL-methionine & 2 & 2 & 2 & \\
\hline Arginine & 1 & & & \\
\hline Vitamin/mineral mixture ${ }^{2}$ & 2 & 2 & 2 & \\
\hline Vitamin E & 0.1 & 0.1 & 0.1 & \\
\hline $\mathrm{BHT}^{3}$ & 0.1 & 0.1 & 0.1 & \\
\hline Robenidine $^{4}$ & 0.8 & 0.8 & 0.8 & \\
\hline \multicolumn{5}{|l|}{ Chemical composition } \\
\hline Dry matter $\left(\mathrm{DM} ; \mathrm{g} \mathrm{kg}^{-1}\right)$ & 912 & 913 & 914.7 & 912 \\
\hline Ash & 116 & 105 & 91.4 & 91 \\
\hline Ether extract (EE) & 30 & 36 & 45.1 & 33 \\
\hline Crude fibre $(\mathrm{CF})$ & 180 & 136 & 132.6 & 165 \\
\hline Neutral detergent fibre (NDF) & 340 & 309 & 250.4 & 352 \\
\hline Acid detergent fibre (ADF) & 198 & 174 & 130.8 & 184 \\
\hline Lignin detergent fibre (ADL) & 28 & 24 & 13.6 & 31 \\
\hline Crude protein $(\mathrm{CP})$ & 171 & 179 & 194.7 & 184 \\
\hline Digestible protein (DP) & 112 & 129 & 146 & 129 \\
\hline Digestible energy (DE; $\left.\mathrm{MJ} \mathrm{kg}^{-1} \mathrm{DM}\right)$ & 10.9 & 12.3 & 13.5 & 12.4 \\
\hline $\mathrm{DE} / \mathrm{DP}\left(\mathrm{kJ} \mathrm{g}^{-1}\right)$ & 97.3 & 95.3 & 92.5 & 96.1 \\
\hline \multicolumn{5}{|c|}{$\begin{array}{l}{ }^{1} 650 \mathrm{~g} \mathrm{~kg}^{-1} \mathrm{lard}, 250 \mathrm{~g} \mathrm{~kg}^{-1} \text { tallow and } 100 \mathrm{~g} \mathrm{~kg}^{-1} \text { poultry fat. } \\
{ }^{2} \mathrm{Contains}\left(\mathrm{g} \mathrm{kg}^{-1}\right) \text { : thiamin, } 0.25 ; \text { riboflavin, } 1.5 ; \text { calcium pantothenate, } 5 \text {; pyridoxine, } 0.1 ; \text { nicotinic acid, } \\
12.5 ; \text { retinol, } 2 ; \text { cholecalciferol, } 0.1 ; \alpha \text {-tocopherol, } 15 ; \text { phytylmenaquinone, } 0.5 ; \text { cyanocobalamin } 0.006 ; \text { cho- } \\
\text { line chloride, } 100 ; \mathrm{MgSO}_{4} \cdot \mathrm{H}_{2} \mathrm{O}, 7.5 ; \mathrm{ZnO}, 30 ; \mathrm{FeSO}_{4} \cdot 7 \mathrm{H}_{2} \mathrm{O}, 20 ; \mathrm{CuSO}_{4} \cdot 5 \mathrm{H}_{2} \mathrm{O}, 3 ; \mathrm{KI}, 0.5 ; \mathrm{CoCl}_{2} \cdot 6 \mathrm{H}_{2} \mathrm{O}, 0.2 ; \\
\mathrm{Na}_{2} \mathrm{SeO}_{3}, 0.03 \text {. } \\
{ }_{3} \mathrm{BHT} \text { (butylhydroxytoluene): antioxidant. } \\
{ }^{4} \text { Robenidine: coccidiostatic. } \\
{ }^{5} \text { Cunicebial CD-14 (Nutreco): commercial diet for reproductive rabbit does (ingredients are not available). }\end{array}$} \\
\hline
\end{tabular}

Chemists [16] for DM, ash, crude protein (CP), ether extract (EE) and crude fibre (CF), and [17] for fibre fractions, with a thermostable amylase pre-treatment. Gross energy (GE) was determined by adiabatic bomb calorimetry following the recommendation of the European Group on Rabbit Nutrition [18]. 


\subsection{Animals and experimental procedures}

A total of sixty-six young males from line $\mathrm{R}$ of the Animal Breeding farm of the Animal Science Department (DCA) of the Polytechnic University of Valencia (UPV) were used in this experiment. Line $\mathrm{R}$ is characterised by a selection criterion based on the growth rate from weaning to slaughter (28-63 days of age) [19], actually showing a growth rate around $50 \mathrm{~g}$ per day.

Only litters with at least three siblings (males) were used in the present experiment. The animals were collectively housed in the Animal Breeding farm of UPV and fed the same commercial diet for growing rabbits until Spanish commercial slaughter date (63 days). From this moment, each sibling was assigned to a different dietary treatment in order to avoid kinship effects and they were housed in individual cages of males for AI in the Animal Nutrition farm of UPV with light alternating on a cycle of 16 light hours and 8 dark hours, and under controlled environmental conditions (cooling).

Rearing diets (L, M and $\mathrm{H}$ ) were offered ad libitum to males until first semen collection at the 24th week of age (usual management for males destined to AI). From this moment and until the end of the trial, all animals received the same diet $(\mathrm{C})$, also offered ad libitum.

The animals were studied during two different seasons of the year (the autumn and the spring). For the autumn group, a total of 36 males fattened during the August-September (mean temperature $\left(\mathrm{T}^{\mathrm{a}} \mathrm{m}\right) 23.6^{\circ} \mathrm{C}$ ) period were controlled during rearing (October to December; $\mathrm{T}^{\mathrm{a}} \mathrm{m} 16.5^{\circ} \mathrm{C}$ ) and semen collection periods (December to February; $\mathrm{T}^{\mathrm{a}} \mathrm{m} 13.0^{\circ} \mathrm{C}$ ). The spring group (30 males) was fattened during the January-February period $\left(\mathrm{T}^{\mathrm{a}} \mathrm{m} 13.0^{\circ} \mathrm{C}\right)$, and then controlled during rearing (March to May; $\mathrm{T}^{\mathrm{a}} \mathrm{m} 18.0{ }^{\circ} \mathrm{C}$ ) and semen collection periods (May to July; $\mathrm{T}^{\mathrm{a}} \mathrm{m} 21.0^{\circ} \mathrm{C}$ ).
Individual live weight and feed intake was controlled weekly throughout the trial. Perirenal fat thickness of males (PFT) was measured monthly by ultrasound to evaluate the body condition, as described by [20]. Fur was removed from the thoracic and lumbar vertebrae area by shearing to improve image retrieval. The animals were situated in an immobilising box $(150 \times$ $370 \mathrm{~mm}$ ) during ultrasound measurement and ultrasound gel (Eko Gel) was applied to the scanning area. The probe was always placed in the same position to obtain a repeatable transversal section of perirenal fat at $3 \mathrm{~cm}$ ahead of the 2 nd to $3 \mathrm{rd}$ lumbar vertebrae. Images were obtained with an ultrasound unit (JustVision real-time machine; Toshiba) equipped with a 5.0 to $8.0 \mathrm{MHz}$ sector probe, and PFT was measured with the image processing system of the equipment.

The experimental procedures of the present work fully agreed with the standards for use of animals established by the Ethical Committee of the Polytechnic University of Valencia.

\subsection{Semen collection and evaluation}

From the 24th week of age, data from 14 and 12 weeks of sexual activity were recorded for the autumn and spring groups, respectively. Two ejaculates per male were collected each week (obtained on the same day with a lag of $30 \mathrm{~min}$ ) using an artificial vagina and the samples were maintained at room temperature and analysed within $1 \mathrm{~h}$. Semen samples were analysed in the Laboratory of Reproduction Biotechnology of UPV. Semen volume was measured in a graduated conical tube. A sperm sample was fixed with a solution of glutaraldehyde $0.25 \%$ in Dulbecco Phosphate Buffered Saline [21] to measure concentration and perform the morphological evaluation. Sperm concentration was calculated by a Thoma-Zeiss cell chamber (final dilution: $1: 50$ ), and the proportion of sperm with a normal apical ridge (NAR), morphologically abnormal sperm and cytoplasmic 
droplets were estimated at a magnification of $400 \times$ with a differential interference contrast microscope (Nomarski contrast).

Kinetic parameters of semen samples were estimated by CASA (ComputerAssisted Sperm Analysis). Aliquots $(10 \mu \mathrm{L})$ of semen diluted 1:50 with Tris-citric acidglucose extender (300 $\left.\mathrm{mOsm} \mathrm{kg}^{-1} ; \mathrm{pH} 6.8\right)$ were laid over a pre-warmed slide at $37^{\circ} \mathrm{C}$ and 4 fields ( 2 drops $\times 2$ fields) or 2 fields ( 2 drops $\times 1$ field) were analysed by CASA (SCA 4.0, Microptic, Spain) using setup parameters previously established for better discriminating granules from static cells. Recorded sperm parameters were the following: total motile sperm percentage (MOT), percentage of medium and fast sperm (MED, HIG) and good motile sperm percentage $(\mathrm{M}+\mathrm{H})$, curvilineal, straight line and average path velocity (VCL, VSL and VAP, respectively; $\mathrm{mm} \mathrm{s}^{-1}$ ), linearity $(\mathrm{LIN}=$ $[\mathrm{VSL} / \mathrm{VCL}] \times 100)$ and wobble $(\mathrm{WOB}=$ [VAP/VCL] $\times 100$ ), amplitude of lateral head displacement (ALH; $\mu \mathrm{m})$, angularity index (AI; \%) and beat cross frequency (BCF; Hz).

\subsection{Statistical analysis}

Statistical analyses of data were carried out with SAS (Statistical Analysis System Institute, 1990). The data were analysed using a mixed procedure (PROC MIXED) and according to a repeated measures design that takes into account the variation between animals and covariation within them. Covariance structures of mixed procedure were objectively compared using the most severe criteria (Schwarz Bayesian criterion), as suggested by [22].

For the analysis of live weight, feed intake and PFT evolution of males and for the motility parameters of their semen, a model considering the fixed effect of the rearing diet, the year season and their interaction was used. For the analysis of quantitative and qualitative semen parameters of males, the model used considered the fixed effects of the diets, the year season, the semen collection month and their interactions, the number of ejaculates recovered weekly being included as a covariate.

\section{RESULTS}

\subsection{Performance traits}

The effects of the rearing diet and rearing season on the live weight, feed intake and PFT evolution of males are presented in Table II. The type of the diet used during the rearing period had no effect on the live weight of the males, showing similar values for the different diets in both seasons and during the whole experimental period. However, the rearing season did have a clear effect upon the live weight of the males. The males controlled during the spring season presented a significantly higher weight at weaning $(+88 \mathrm{~g} ; P<0.001)$ and on the slaughter date $(+316 \mathrm{~g} ; P<$ 0.001 ) than those reared during the autumn season, and these differences were maintained at the beginning of semen collection $(+261 \mathrm{~g} ; P<0.001)$ and until the end of the trial (Fig. 1).

Males showed a significantly lower feed intake as the DE content of the diet increased from the 9th to the 14th week of age, but the DE and DP intake of the animals was higher as the DE content increased $(P<0.10$ and $P<0.05$, respectively). Feed intake regulation in accordance with the DE content of the diets was maintained until the beginning of semen collection, but on the contrary to that observed during the first month after the slaughter date, the animals receiving the $\mathrm{H}$ diet showed on average a lower DE and DP intake $(P<0.001$ and $P<0.05$, respectively). Since all the animals received the same diet from the 24 th week of age on, differences between the dietary treatments in feed intake clearly decreased from this moment on, although DE and DP intake values were lower for the animals that received the $\mathrm{H}$ diet during the rearing time

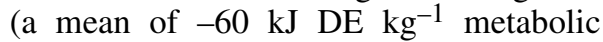


Table II. Effect of the energy rearing diet and the rearing season on the live weight and food intake evolution of males ${ }^{1}$.

\begin{tabular}{|c|c|c|c|c|c|c|c|c|c|}
\hline & \multicolumn{3}{|c|}{ Autumn season } & \multicolumn{3}{|c|}{ Spring season } & \multirow[b]{2}{*}{ s.e. } & \multicolumn{2}{|c|}{ Signification $^{2}$} \\
\hline & $\mathrm{L}$ & M & $\mathrm{H}$ & $\mathrm{L}$ & M & $\mathrm{H}$ & & $\mathrm{D}$ & $\mathrm{S}$ \\
\hline \multicolumn{10}{|l|}{ Live weight (g) } \\
\hline at 4 weeks of age (weaning) & $538^{\mathrm{a}}$ & $511^{\mathrm{a}}$ & $491^{\mathrm{a}}$ & $613^{\mathrm{b}}$ & $612^{\mathrm{b}}$ & $580^{\mathrm{ab}}$ & 33 & & $* * *$ \\
\hline at 9 weeks of age & $2148^{\mathrm{a}}$ & $2134^{\mathrm{a}}$ & $2054^{\mathrm{a}}$ & $2398^{b}$ & $2466^{\mathrm{b}}$ & $2422^{b}$ & 60 & & $* * *$ \\
\hline at 24 weeks of age & $4375^{\mathrm{a}}$ & $4548^{\mathrm{ab}}$ & $4495^{\mathrm{ab}}$ & $4911^{\mathrm{c}}$ & $4796^{\mathrm{bc}}$ & $5091^{\mathrm{c}}$ & 135 & & $* * *$ \\
\hline at 32 weeks of age & 4816 & 4856 & 4832 & 5123 & 5136 & 5071 & 150 & & * \\
\hline \multicolumn{10}{|c|}{ Feed intake $\left(\mathrm{g} \mathrm{DM} \mathrm{kg}^{-1} \mathrm{LW}^{0.75} \mathrm{~d}^{-1}\right)$} \\
\hline 9 to 14 weeks of age & $71.47^{\mathrm{c}}$ & $65.93^{\mathrm{b}}$ & $59.29^{a}$ & $82.45^{\mathrm{d}}$ & $72.40^{\mathrm{c}}$ & $64.98^{b}$ & 1.68 & $* * *$ & $* * *$ \\
\hline 15 to 24 weeks of age & $66.56^{\mathrm{bc}}$ & $59.75^{\mathrm{b}}$ & $50.12^{\mathrm{a}}$ & $68.58^{\mathrm{c}}$ & $57.66^{\mathrm{b}}$ & $49.62^{\mathrm{a}}$ & 1.25 & $* * *$ & \\
\hline 25 to 28 weeks of age & $53.13^{c}$ & $53.67^{c}$ & $48.90^{\mathrm{bc}}$ & $51.54^{\mathrm{c}}$ & $44.72^{\mathrm{bc}}$ & $41.40^{\mathrm{a}}$ & 2.26 & $*$ & $* * *$ \\
\hline 29 to 37 weeks of age & $50.35^{\mathrm{b}}$ & $47.88^{\mathrm{b}}$ & $45.78^{b}$ & $37.21^{\mathrm{a}}$ & $39.70^{\mathrm{a}}$ & $36.92^{\mathrm{a}}$ & 2.51 & & $* * *$ \\
\hline \multicolumn{10}{|c|}{ Energy intake $\left(\mathrm{kJ} \mathrm{DE} \mathrm{kg}^{-1} \mathrm{LW}^{0.75} \mathrm{~d}^{-1}\right)$} \\
\hline 9 to 14 weeks of age & $779^{a}$ & $811^{\mathrm{b}}$ & $800^{\mathrm{b}}$ & $899^{c}$ & $890^{\mathrm{c}}$ & $877^{\mathrm{c}}$ & 9 & & $* * *$ \\
\hline 15 to 24 weeks of age & $725^{\mathrm{b}}$ & $735^{\mathrm{b}}$ & $677^{\mathrm{a}}$ & $858^{\mathrm{d}}$ & $832^{\mathrm{d}}$ & $806^{\mathrm{c}}$ & 11 & $* * *$ & $*$ \\
\hline 25 to 28 weeks of age & $659^{b}$ & $666^{\mathrm{b}}$ & $606^{\mathrm{b}}$ & $639^{b}$ & $554^{\mathrm{ab}}$ & $513^{\mathrm{a}}$ & 29 & $*$ & $* *$ \\
\hline 29 to 37 weeks of age & $625^{\mathrm{c}}$ & $594^{\mathrm{bc}}$ & $568^{\mathrm{b}}$ & $462^{\mathrm{a}}$ & $492^{\mathrm{a}}$ & $458^{\mathrm{a}}$ & 22 & $*$ & $* * *$ \\
\hline \multicolumn{10}{|c|}{ Protein intake (g DP kg ${ }^{-1} \mathrm{LW}^{0.75} \mathrm{~d}^{-1}$ ) } \\
\hline 9 to 14 weeks of age & $8.00^{\mathrm{a}}$ & $8.51^{\mathrm{ab}}$ & $8.67^{\mathrm{b}}$ & $9.24^{\mathrm{c}}$ & $9.34^{\mathrm{c}}$ & $9.49^{c}$ & 0.21 & $*$ & $* * *$ \\
\hline 15 to 24 weeks of age & $7.45^{\mathrm{b}}$ & $7.70^{\mathrm{b}}$ & $7.32^{\mathrm{ab}}$ & $7.66^{\mathrm{b}}$ & $7.44^{\mathrm{a}}$ & $7.23^{\mathrm{a}}$ & 0.16 & $*$ & \\
\hline 25 to 28 weeks of age & $6.85^{\mathrm{c}}$ & $6.92^{\mathrm{c}}$ & $6.31^{\mathrm{bc}}$ & $6.65^{\mathrm{c}}$ & $5.77^{\mathrm{ab}}$ & $5.34^{\mathrm{a}}$ & 0.30 & $*$ & $* * *$ \\
\hline 29 to 37 weeks of age & $6.50^{\mathrm{b}}$ & $6.18^{\mathrm{b}}$ & $5.91^{\mathrm{b}}$ & $4.80^{\mathrm{a}}$ & $5.13^{\mathrm{a}}$ & $4.77^{\mathrm{a}}$ & 0.31 & & $* * *$ \\
\hline \multicolumn{10}{|l|}{ Perirenal fat thickness (mm) } \\
\hline at 9 weeks of age & 7.78 & 7.61 & 7.59 & 7.23 & 7.63 & 7.45 & 0.20 & & \\
\hline at 24 weeks of age & $10.40^{\mathrm{b}}$ & $10.70^{\mathrm{b}}$ & $10.30^{\mathrm{ab}}$ & $9.64^{\mathrm{a}}$ & $9.82^{\mathrm{a}}$ & $9.86^{\mathrm{a}}$ & 0.19 & & $* *$ \\
\hline at 32 weeks of age & 10.30 & 10.11 & 9.91 & 10.09 & 9.84 & 10.14 & 0.22 & & \\
\hline
\end{tabular}

a,b,c,d Means for the diets within a row with different superscripts are significantly different $(P<0.05)$ $* P<0.05$; *** $P<0.001$.

Rearing diets: low (L), medium (M) and high (H) energy content.

${ }^{1}$ Animals were weaned at 28 days of age (4 week), fatted in collective cages until 63 days of age (commercial Spanish slaughter date) and then caged in individual cages. Semen collection begins at 24 weeks of age.

${ }^{2}$ Signification: Effect of diet (D), season $(\mathrm{S})$. None $\mathrm{D} \times \mathrm{S}$ interactions were observed.

weight $\left(\mathrm{LW}^{0.75}\right)$ day $^{-1}$ and $-0.6 \mathrm{~g} \mathrm{DP} \mathrm{kg}^{-1}$ $\mathrm{LW}^{0.75}$ day $\left.^{-1}\right)$.

The rearing season had a clear greater effect on the feed intake of the animals than the dietary treatment throughout the trial. Initially, the animals reared during the spring season presented a higher feed intake than those reared during the autumn $\left(+7.8 \mathrm{~g} \mathrm{~kg}^{-1}\right.$
$\mathrm{LW}^{0.75} \mathrm{day}^{-1} ; P<0.001$ ), but as the heat season came closer, the feed intake of the animals clearly decreased, with males in the spring group showing a lower feed intake than autumn males during the semen collection period, especially in the last two months $\left(-10.1 \mathrm{~g} \mathrm{~kg}^{-1} \mathrm{LW}^{0.75}\right.$ day $^{-1} ; P<$ $0.001)$. 


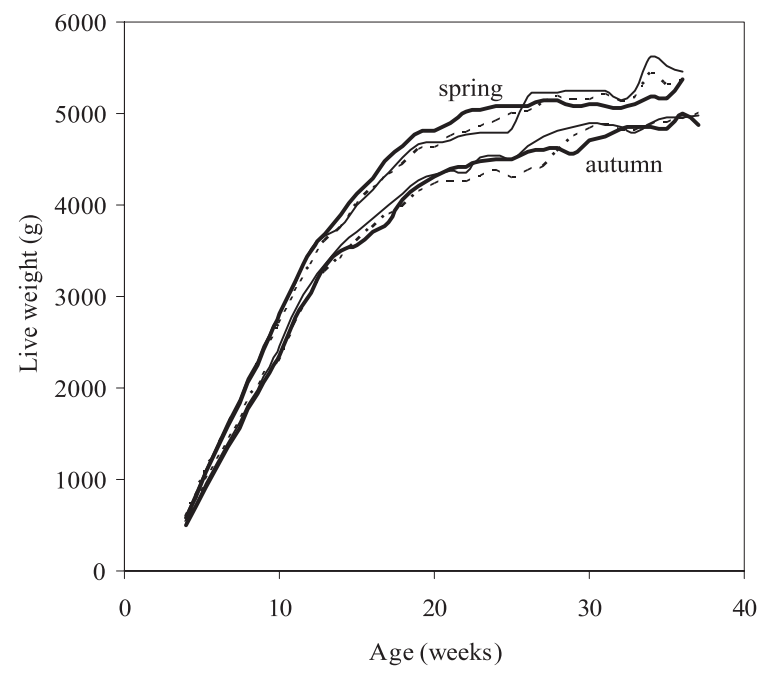

Figure 1. Evolution of live weight of males for the different rearing diets ( $\cdots, M-$ and $\mathrm{H}$ ) and for the different year season (autumn and spring) analysed between weaning (4th week) and the 38 th week of age.

As can be seen in Figure 2, the energy and protein requirements of males were generally easily covered. In the autumn group, males were unable to intake the recommended DP only during their 3rd month of life (9.1 $\left.\mathrm{g} \mathrm{PD} \mathrm{kg}^{-1} \mathrm{LW}^{0.75} \mathrm{day}^{-1}\right)$, especially with low concentrate diets $(8.0,8.5$ and $8.7 \mathrm{~g} \mathrm{DP} \mathrm{kg}^{-1} \mathrm{LW}^{0.75}$ day $^{-1}$ for $\mathrm{L}, \mathrm{M}$ and $\mathrm{H}$ diets, respectively; $P<0.05$ ). In the spring group, the DE energy requirements (490 MJ DE kg ${ }^{-1} \mathrm{LW}^{0.75}$ day $^{-1}$ ) were not covered during the last two months that were controlled independently of dietary treatment (a mean of $470 \mathrm{MJ} \mathrm{DE} \mathrm{kg}^{-1}$ $\mathrm{LW}^{0.75}$ day $\left.^{-1}\right)$.

Although the PFT of males increased from 7.5 to $10.1 \mathrm{~mm}$ during the rearing period (being maintained from the 6th month of age), the type of diet did not affect the PFT of the males throughout the experiment. The season only affected the PFT value of the males at the beginning of semen collection, being higher for the animals reared during the autumn season (10.5 and $9.8 \mathrm{~mm}$ for the autumn and spring groups, respectively; $P<0.01$ ), although these differences disappeared at 32 weeks of age.

\subsection{Seminal parameters}

From the 66 males used in the present trial, a total of 586 semen samples were obtained from only 53 animals (13 males did not give samples because of death, illness or non-mount behaviour). Only 38 animals (13, 12 and 13 for $\mathrm{L}, \mathrm{M}$ and $\mathrm{H}$ diets, respectively), however, presented an adequate reproductive behaviour, assiduously providing semen samples.

Table III shows the effect of the diets received during the rearing time and the mount month on the main quantitative seminal parameters controlled during the autumn and spring seasons. The number of weekly ejaculates recovered per male significantly increased with the mount month $(+0.40$ ejaculates from the 1 st to the 2 nd-3rd months; $P<0.001$ ), and males from the $M$ group tended to show lower values, especially during the autumn season $(-0.35$ ejaculates per male; $P<0.05$ ).

The mean volume of the ejaculates decreased with the mount month during the autumn $(-0.31 \mathrm{~mL}$ per ejaculate from the 1 st to the 3 rd month; $P<0.01$ ), but increased 

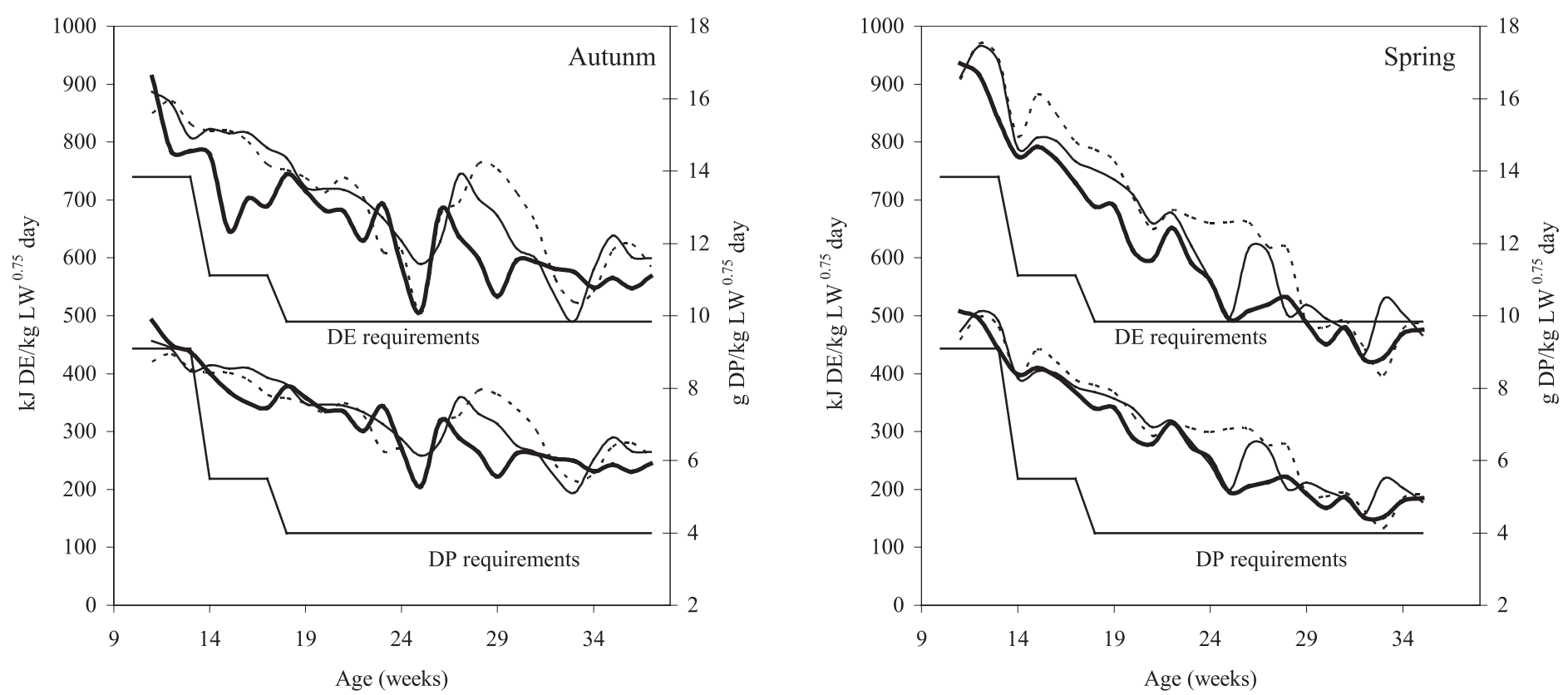

Figure 2. Evolution of digestible energy (DE) and protein (DP) intake of males with the different rearing diets (L . ., M $\longrightarrow$ and $\mathrm{H} \longrightarrow$ ) and for the different year season (autumn and spring) analysed between post commercial slaughter date (9th week) and the 38th week of age. 
Table III. Effect of the energy rearing diet and the month of mating on some quantitative semen parameters of males reared during the autumn and spring seasons.

\begin{tabular}{|c|c|c|c|c|c|c|c|c|c|c|}
\hline & \multicolumn{5}{|c|}{ Autumn season } & \multicolumn{5}{|c|}{ Spring season } \\
\hline & Mean & $\mathrm{L}$ & M & $\mathrm{H}$ & s.e. & Mean & $\mathrm{L}$ & $\mathrm{M}$ & $\mathrm{H}$ & s.e. \\
\hline$\%$ animals a & roduce semen & 55 & 55 & 64 & & & 64 & 55 & 55 & \\
\hline \multicolumn{11}{|c|}{ No. of ejaculate $(n=586)$} \\
\hline 1 st month & $1.316^{\mathrm{A}}$ & $1.469^{\mathrm{b}}$ & $1.042^{\mathrm{a}}$ & $1.438^{\mathrm{b}}$ & 0.048 & $1.437^{\mathrm{A}}$ & $1.543^{\mathrm{b}}$ & $1.255^{\mathrm{a}}$ & $1.513^{\mathrm{b}}$ & 0.048 \\
\hline 2nd month & $1.704^{\mathrm{B}}$ & $1.844^{\mathrm{b}}$ & $1.500^{\mathrm{a}}$ & $1.768^{b}$ & 0.050 & $1.825^{\mathrm{B}}$ & 1.910 & 1.751 & 1.815 & 0.047 \\
\hline 3rd month & $1.864^{\mathrm{C}}$ & $1.969^{b}$ & $1.646^{\mathrm{a}}$ & $1.978^{b}$ & 0.051 & $1.702^{\mathrm{B}}$ & 1.590 & 1.791 & 1.725 & 0.066 \\
\hline s.e. & 0.050 & & & & & 0.062 & & & & \\
\hline Mean & & $1.760^{\mathrm{b}}$ & $1.395^{\mathrm{a}}$ & $1.728^{b}$ & 0.109 & & 1.680 & 1.599 & 1.684 & 0.107 \\
\hline \multicolumn{11}{|c|}{ Volume (mL/ejaculate) $(n=391)^{1}$} \\
\hline 1 st month & $1.021^{\mathrm{B}}$ & 0.985 & 1.093 & 0.985 & 0.056 & $0.802^{\mathrm{A}}$ & 0.795 & 0.722 & 0.888 & 0.057 \\
\hline 2nd month & $0.872^{\mathrm{AB}}$ & 0.776 & 1.009 & 0.829 & 0.051 & $0.894^{\mathrm{AB}}$ & 0.900 & 0.765 & 1.016 & 0.047 \\
\hline 3rd month & $0.710^{\mathrm{B}}$ & 0.779 & 0.609 & 0.741 & 0.055 & $0.984^{\mathrm{B}}$ & 0.900 & 0.936 & 1.127 & 0.063 \\
\hline s.e. & 0.061 & & & & & 0.063 & & & & \\
\hline Mean & & 0.847 & 0.904 & 0.852 & 0.072 & & 0.862 & 0.808 & 1.011 & 0.102 \\
\hline \multicolumn{11}{|c|}{ Spermatozoa $\times \mathbf{1 0}^{6} \cdot \mathbf{m L}^{-1}(n=380)^{1}$} \\
\hline 1 st month & $189.5^{\mathrm{B}}$ & $213.1^{\mathrm{ab}}$ & $104.9^{\mathrm{a}}$ & $250.6^{\mathrm{b}}$ & 22.7 & $283.2^{\mathrm{B}}$ & $416.6^{\mathrm{b}}$ & $120.8^{\mathrm{a}}$ & $312.1^{\mathrm{b}}$ & 39.6 \\
\hline 2nd month & $130.4^{\mathrm{A}}$ & 167.0 & 86.6 & 137.7 & 20.2 & $169.3^{\mathrm{A}}$ & $258.0^{\mathrm{b}}$ & $94.0^{\mathrm{a}}$ & $156.1^{\mathrm{ab}}$ & 32.0 \\
\hline 3rd month & $134.0^{\mathrm{A}}$ & 139.3 & 123.3 & 139.5 & 22.4 & $166.8^{\mathrm{A}}$ & $307.0^{\mathrm{b}}$ & $83.9^{\mathrm{a}}$ & $109.3^{\mathrm{ab}}$ & 45.9 \\
\hline s.e. & 21.8 & & & & & 40.0 & & & & \\
\hline Mean & & $173.1^{\mathrm{ab}}$ & $104.9^{\mathrm{a}}$ & $175.9^{\mathrm{b}}$ & 24.3 & & $327.3^{\mathrm{b}}$ & $99.6^{\mathrm{a}}$ & $192.5^{\mathrm{ab}}$ & 50.0 \\
\hline \multicolumn{11}{|c|}{ Spermatozoa $\times 10^{6} /$ ejaculate $(n=411)$} \\
\hline 1 st month & $206.0^{\mathrm{B}}$ & $171.1^{\mathrm{a}}$ & $202.5^{\mathrm{ab}}$ & $259.3^{\mathrm{b}}$ & 19.6 & $240.5^{\mathrm{B}}$ & $377.9^{\mathrm{b}}$ & $93.7^{\mathrm{a}}$ & $250.0^{\mathrm{ab}}$ & 32.5 \\
\hline 2nd month & $116.4^{\mathrm{A}}$ & 121.6 & 123.4 & 108.1 & 18.6 & $154.7^{\mathrm{A}}$ & $266.2^{b}$ & $84.6^{\mathrm{a}}$ & $113.4^{\mathrm{a}}$ & 25.7 \\
\hline 3rd month & $97.9^{\mathrm{A}}$ & 76.2 & 120.2 & 107.5 & 18.9 & $152.2^{\mathrm{A}}$ & 260.7 & 92.1 & 103.7 & 37.6 \\
\hline s.e. & 19.0 & & & & & 32.0 & & & & \\
\hline Mean & & 123.5 & 148.9 & 158.3 & 27.6 & & $301.6^{\mathrm{b}}$ & $90.1^{\mathrm{a}}$ & $155.7^{\mathrm{ab}}$ & 52.2 \\
\hline
\end{tabular}

a,b,c Means for diets within a row with different superscripts are significantly different $(P<0.05)$.

A,B,C Means for months within a column with different superscripts are significantly different $(P<0.05)$.

Volume and concentration (spermatozoa $\times 10^{6} \cdot \mathrm{mL}^{-1}$ ) data were calculated from non-dirty ejaculates (without urine or blood).

Production (spermatozoa $\times 10 \%$ ejaculate) data were calculated from total ejaculates.

${ }^{1}$ Covariate (no of non-dirty ejaculates) affected significantly $P<0.05$.

Rearing diets: low (L), medium $(\mathrm{M})$ and high $(\mathrm{H})$ energy content.

during the spring season $(+0.18 \mathrm{~mL}$ per ejaculate from the 1 st to the 3 rd month; $P<$ 0.05). The type of diet received during the rearing season had no effect on the mean volume of the ejaculates.

The mean concentration of semen was higher in the first collecting month than in the following months during both seasons $\left(+85 \times 10^{6}\right.$ spermatozoa per $\left.\mathrm{mL} ; P<0.001\right)$ and consequently semen production showed a similar tendency $\left(+90 \times 10^{6}\right.$ spermatozoa per ejaculate for the first month; $P<0.001$ ). With respect to the effect of the rearing diet, the $\mathrm{H}$ males showed higher semen concentration and production during the autumn season, mainly due to their greater values 
Table IV. Effect of the energy rearing diet and the month of mating on some qualitative semen parameters of males reared during the autumn and spring seasons $(n=407)$.

\begin{tabular}{|c|c|c|c|c|c|c|c|c|c|c|}
\hline & \multicolumn{5}{|c|}{ Autumn season } & \multicolumn{5}{|c|}{ Spring season } \\
\hline & Mean & $\mathrm{L}$ & M & $\mathrm{H}$ & s.e. & Mean & $\mathrm{L}$ & M & $\mathrm{H}$ & s.e. \\
\hline \multicolumn{11}{|c|}{ Acrosoma integrity (\%) } \\
\hline 1st month & $85.67^{\mathrm{AB}}$ & 80.25 & 81.30 & 83.46 & 1.95 & $85.29^{\mathrm{B}}$ & 85.93 & 86.46 & 83.50 & 0.88 \\
\hline 2nd month & $80.74^{\mathrm{A}}$ & $70.46^{\mathrm{a}}$ & $74.56^{\mathrm{a}}$ & $88.20^{\mathrm{b}}$ & 1.71 & $84.42^{\mathrm{B}}$ & 84.68 & 84.77 & 83.81 & 0.70 \\
\hline 3rd month & $86.11^{\mathrm{B}}$ & 81.10 & 90.69 & 86.53 & 1.89 & $81.64^{\mathrm{A}}$ & 80.68 & 83.09 & 81.17 & 1.04 \\
\hline s.e. & 1.76 & & & & & 0.87 & & & & \\
\hline Mean & & 80.27 & 82.18 & 86.06 & 4.63 & & 83.76 & 84.77 & 82.82 & 1.11 \\
\hline \multicolumn{11}{|c|}{ Sperm abnormalities (\%) } \\
\hline 1st month & 6.23 & 5.13 & 7.60 & 5.98 & 0.83 & 7.24 & 9.73 & 5.67 & 6.31 & 0.77 \\
\hline 2nd month & 7.35 & 7.66 & 8.30 & 6.09 & 0.78 & 7.72 & 9.47 & 6.64 & 7.05 & 0.62 \\
\hline 3rd month & 6.08 & $5.82^{\mathrm{ab}}$ & $8.25^{\mathrm{b}}$ & $4.18^{a ̀}$ & 0.81 & 9.30 & $13.80^{b}$ & $8.11^{\mathrm{a}}$ & $6.00^{\mathrm{a}}$ & 0.91 \\
\hline s.e. & 0.55 & & & & & 0.77 & & & & \\
\hline Mean & & 6.21 & 8.05 & 5.41 & 2.03 & & 11.00 & 6.81 & 6.45 & 2.10 \\
\hline \multicolumn{11}{|c|}{ Protoplasmatic drop $(\%)$} \\
\hline 1st month & 16.58 & $22.01^{\mathrm{b}}$ & $14.81^{\mathrm{ab}}$ & $12.92^{\mathrm{a}}$ & 1.54 & 13.20 & 13.42 & 11.28 & 14.90 & 0.95 \\
\hline 2nd month & 15.66 & 16.67 & 17.26 & 13.06 & 1.45 & 10.87 & 12.07 & 9.83 & 10.69 & 0.76 \\
\hline 3rd month & 15.30 & $17.23^{\mathrm{b}}$ & $18.64^{\mathrm{b}}$ & $10.03^{\mathrm{a}}$ & 1.50 & 11.62 & 12.74 & 10.26 & 11.86 & 1.11 \\
\hline s.e. & 2.03 & & & & & 0.94 & & & & \\
\hline Mean & & $18.64^{\mathrm{b}}$ & $16.90^{\mathrm{ab}}$ & $12.00^{\mathrm{a}}$ & 2.55 & & 12.75 & 10.46 & 12.49 & 2.33 \\
\hline
\end{tabular}

a,b,c Means for diets within a row with different superscripts are significantly different $(P<0.05)$.

A,B,C Means for months within a column with different superscripts are significantly different $(P<0.05)$.

Rearing diets: low (L), medium (M) and high (H) energy content.

during the 1 st mount month $\left(+88 \times 10^{6}\right.$ spermatozoa per ejaculate; $P<0.05)$. However, L males showed higher semen concentration and production than the $\mathrm{M}$ males during the spring season, with the $\mathrm{H}$ group showing intermediate values $\left(+180 \times 10^{6}\right.$ spermatozoa per ejaculate; $P<0.001)$.

The mean number of ejaculates and volume of semen were similar for both seasons (1.6 ejaculates and $0.88 \mathrm{~mL} /$ ejaculate, respectively). However, the males reared during the spring season showed significantly higher values for sperm concentration $\left(+55 \times 10^{6}\right.$ spermatozoa per $\mathrm{mL} ; P<$ $0.01)$ and production $\left(+42 \times 10^{6}\right.$ spermatozoa per ejaculate; $P<0.01)$.

Table IV shows the results concerning the main qualitative semen parameters of males in line with the rearing diet, mount month and rearing season. The lowest values for the normal apical ridge were obtained at the 2nd and 3rd months during the autumn and the spring seasons respectively $(P<0.05)$, not being significantly affected by the rearing diet received by males (although the $\mathrm{H}$ group presented higher values during the autumn season).

The mount month did not affect the percentage of sperm abnormalities, nor the proportion of spermatozoa with cytoplasmic droplets. However, $\mathrm{H}$ males presented a lower percentage of spermatozoa with cytoplasmic droplets than the $\mathrm{L}$ group $(-6.6 \% ; P<0.05)$ as well as the lowest values for sperm abnormalities during the autumn season. Differences between the 
Table V. Effect of the energy rearing diet and the rearing season on semen motility parameters.

\begin{tabular}{|c|c|c|c|c|c|c|c|c|c|c|}
\hline & \multicolumn{3}{|c|}{ Autumn season } & \multicolumn{3}{|c|}{ Spring season } & \multicolumn{4}{|c|}{ Signification $^{3}$} \\
\hline & $\mathrm{L}$ & M & $\mathrm{H}$ & $\mathrm{L}$ & M & $\mathrm{H}$ & s.e. & $\mathrm{D}$ & $\mathrm{S}$ & $\mathrm{D} \times \mathrm{S}$ \\
\hline \multicolumn{11}{|l|}{ Motility parameters } \\
\hline Total motility (MOT; \%) & $47.73^{b}$ & $37.38^{\mathrm{ab}}$ & $44.39^{\mathrm{b}}$ & $36.97^{\mathrm{ab}}$ & $47.01^{b}$ & $30.57^{\mathrm{a}}$ & 3.00 & & & $* *$ \\
\hline Medium motility (MED;\%) & 6.71 & 5.75 & 5.59 & 5.34 & 6.57 & 4.48 & 0.82 & & & \\
\hline High motility (HIG;\%) & $10.86^{\mathrm{ab}}$ & $5.21^{\mathrm{a}}$ & $9.23^{\mathrm{ab}}$ & $5.22^{\mathrm{a}}$ & $14.26^{\mathrm{b}}$ & $6.01^{\mathrm{a}}$ & 1.39 & & & $* * *$ \\
\hline Good motility $(\mathrm{M}+\mathrm{H} ; \%)^{1}$ & $17.57^{\mathrm{ab}}$ & $10.96^{\mathrm{a}}$ & $14.82^{\mathrm{ab}}$ & $10.57^{\mathrm{a}}$ & $20.82^{\mathrm{b}}$ & $10.49^{\mathrm{a}}$ & 1.92 & & & $* *$ \\
\hline \multicolumn{11}{|l|}{ Rate parameters } \\
\hline Track speed $\left(\mathrm{TS} ; \mu \mathrm{m} \mathrm{s}^{-1}\right)$ & $43.85^{\mathrm{b}}$ & $35.10^{\mathrm{a}}$ & $42.60^{\mathrm{b}}$ & $38.83^{\mathrm{ab}}$ & $46.52^{b}$ & $40.64^{\mathrm{ab}}$ & 1.79 & & & $* *$ \\
\hline Progressive speed $\left(\operatorname{PrS} ; \mu \mathrm{m} \mathrm{s}^{-1}\right)$ & $20.37^{b}$ & $15.45^{\mathrm{ab}}$ & $17.66^{\mathrm{ab}}$ & $14.44^{\mathrm{a}}$ & $19.79^{\mathrm{ab}}$ & $16.38^{\mathrm{ab}}$ & 1.40 & & & $*$ \\
\hline Path speed $\left(\mathrm{PaS} ; \mu \mathrm{m} \mathrm{s}^{-1}\right)$ & $24.91^{b}$ & $19.73^{\mathrm{ab}}$ & $22.81^{\mathrm{ab}}$ & $19.30^{\mathrm{a}}$ & $24.98^{b}$ & $21.47^{\mathrm{ab}}$ & 1.35 & & & $*$ \\
\hline Linearity index (LIN; \%) ${ }^{2}$ & 46.18 & 49.93 & 43.34 & 40.53 & 44.02 & 41.28 & 2.35 & & + & \\
\hline Oscillation index (OSC; \%) & 58.59 & 61.94 & 57.25 & 54.73 & 56.79 & 55.22 & 1.70 & & + & \\
\hline \multicolumn{11}{|c|}{ Angularity and beaten parameters } \\
\hline $\begin{array}{l}\text { Amplitude of lateral head } \\
\text { displacement (ALH; } \mu \mathrm{m})\end{array}$ & 1.77 & 1.59 & 1.91 & 1.91 & 2.09 & 1.92 & 0.12 & & & \\
\hline Angularity index (AI; \%) & 28.58 & 24.78 & 28.59 & 27.96 & 30.35 & 31.58 & 1.61 & & & \\
\hline Beat cross frequency (BCF; $\mathrm{Hz})$ & 8.23 & 7.52 & 10.96 & 10.02 & 9.53 & 9.85 & 0.72 & & & \\
\hline
\end{tabular}

a,b,c Means for diets within a row with different superscripts are significantly different $(P<0.05)$

$+P<0.10 ; * P<0.05 ; * * P<0.01 ; * * * P<0.001$.

Rearing diets: low $(\mathrm{L})$, medium $(\mathrm{M})$ and high $(\mathrm{H})$ energy content.

${ }^{1}$ Good motility $=$ medium motility + high motility.

${ }^{2}$ Linearity $(\mathrm{LIN}=[\mathrm{Pr} / \mathrm{TS}] \times 100)$.

${ }^{3}$ Signification: Effect of diet (D), season (S) and the interaction $(\mathrm{D} \times \mathrm{S})$.

dietary treatments disappeared during the spring season, although the L group presented higher abnormality percentages, especially during the last month controlled $(+6.8 \% ; P<0.05)$.

Finally, the effect of the rearing diet on semen motility parameters of males reared during the autumn and spring seasons is shown in Table V. Dietary treatment did not affect any of the motility parameters controlled for the males reared during the autumn season and only one rate parameter was lower for the $\mathrm{M}$ group $\left(-8.1 \mu \mathrm{m} \mathrm{s}^{-1}\right.$ for VCL; $P<0.05)$. In the case of spring rearing, semen from the $\mathrm{M}$ group presented higher MOT, HIG and $\mathrm{M}+\mathrm{H}$ values $(P<$ 0.01 ), while semen from the $\mathrm{L}$ group showed the lowest values of VSL and VAP
$(P<0.05)$, but the other motility parameters controlled were not affected by the rearing diet received.

\section{DISCUSSION}

The conversion rate seems to be the most adequate criterion, from an economical point of view, to improve rabbit meat lines [23]. However, growth rate is usually the selected criterion due to the management problems of a program based on the conversion rate of the animals. The growth rate of males selected by this criterion, and consequently their nutritional requirements [14], has clearly changed in recent years, from $40-45 \mathrm{~g} \mathrm{day}^{-1}$ to $50-55 \mathrm{~g} \mathrm{day}^{-1}$ during the growing period ( 28 to 63 days of age). In fact, our animals presented a mean 
growth rate of $50 \mathrm{~g} \mathrm{day}^{-1}$ during the growing period, changing to $42 \mathrm{~g}$ day $^{-1}$ during the 3rd month of life and falling thereafter to values close to $0-10 \mathrm{~g} \mathrm{day}^{-1}$.

Following the recommendations of ParigiBini and Xiccato [24] and Fraga [25], the energy and protein requirements of males selected for growth rate could be calculated as in Figure 2. As a general rule, DE and DP requirements were easily covered throughout the trial with the different dietary treatments and independently of the rearing season. However, although the nutrient requirements of males seem to be well met in males reared during the spring, the DP requirements will be only covered with the $\mathrm{H}$ diet from the 9th to the 13th week of age on males fattened during the summer $(9 \mathrm{~g}$ $\left.\mathrm{DP} \mathrm{kg}{ }^{-1} \mathrm{LW}^{0.75} \mathrm{day}^{-1}\right)$. This protein deficit could affect the performance of males receiving the $\mathrm{L}$ and $\mathrm{M}$ diets, and could perhaps explain the slightly better results obtained for $\mathrm{H}$ animals only for the autumn group on the main seminal parameters controlled (semen production, sperm abnormalities, cytoplasmic droplets).

Many authors have observed a lower feed intake and growth rate of rabbits fattened under hot conditions [26]. In the present work, autumn reared males already presented a lower live weight at the beginning of the dietary treatment than spring reared males, and the differences were maintained until the end of the experiment. In addition, the spring reared males showed a higher feed intake during the rearing period than the autumn reared males, although it decreased during the semen collection period due to the proximity of the summer.

In general, sperm volumes were slightly higher in the spring than in the autumn, as has previously been reported in other works [27, 28]. At the same time, concentrations obtained in the spring were in general higher than those obtained in the autumn, which was very pronounced for the group of males that had been fed with the low energy diet during the rearing period. Several authors have observed higher concentrations and productions in semen collected during the spring than after the hot season [29]. With regards to the quantitative seminal parameters, it was observed that the group from the spring season which had been fed the high energy diet presented higher volumes of semen than those fed with the low energy or the control diets. Louis et al. [30] reported that boars fed low energy diets had reduced libido and semen volume and sperm output than those fed high energy diets. In our work, males fed the low energy diet presented a higher concentration and, as a consequence, higher production than male rabbits fed the high energy and control diets. However, in the group of males whose semen was obtained from October to December (autumn season), the volume values were higher in the control group and the concentration values were higher in the groups fed with $\mathrm{H}$ and L energy diets, obtaining a higher sperm production in the group of males fed high energy diets.

Therefore, the future reproductive males fattened during the summer season usually present a worse performance during the growing period than those fattened during the winter season, which could affect the subsequent performance. This lower performance and higher temperature suffered 2 months after could be the reasons for the worse sperm production results obtained for the autumn group and the positive effect observed when highly concentrated diets were used during rearing. However, this type of diet should not have any advantage in the case of animals that are well developed and with higher intake ability, the use of a moderate energy diet perhaps being more adequate in order to avoid an excessive fatness and an adequate performance of future males for AI. Intensive feeding of young bulls can result in lowered reproductive performance probably due to an excessive fat deposition around the testis, which would hinder their correct thermoregulation, leading to a reduction in sperm production (for a review, see [31]). 
On contrary, and as observed by [14], although rabbit males selected for growth rate are able to cover the energy requirements with a diet similar to commercial feeds (10.5 MJ ED per kg) during the growing period, protein requirements were difficult to meet with this type of feed $(107 \mathrm{~g}$ PD per kg) especially when feed intake was lower than $150 \mathrm{~g}$ per day (hot seasons).

As for the morphological evaluation of sperm, the results observed in the present work were similar to those reported by other authors working with males of the same rabbit line (85\% observed by [32]). The percentage of spermatozoa with cytoplasmic droplets was higher than that reported by other authors working with adult males of the same line (11\%, [29]) which is probably due to the youth of the animals (since ejaculates from young males frequently have a high percent of sperm with droplets, [33]).

The motility rate observed in this experiment was lower than the motility rate reported by other authors when working with fresh semen (usually higher than $70 \%$ of motile sperm [32, 34, 35]). This could have been due to the high dilution rate used in this work (dilution 1:50) to measure the motility parameters with the CASA system; [36] observed a pronounced reduction in motility parameters from rabbit spermatozoa when seminal plasma had been diluted more than 30 fold. With respect to the other motility parameters measured in this work, they were similar to those reported by [37] working with sperm from the same line, but clearly lower than those reported by other authors using the same CASA system $[36,38]$.

In any case, the results of the present work seem to indicate that the management of males during the growing and rearing periods (especially the season) seems to significantly affect their subsequent performance and semen production. The development of early management programs that should consider the adequate feeding program according to the housing (environmental) conditions of males is therefore advisable.

In conclusion, males receiving high energy rearing diets during the autumn had a higher concentration and sperm production and those receiving low energy rearing diets during the spring had a higher quantitative production. In general, males reared during the spring had a higher weight at weaning, concentration and sperm production with a lower percentage of spermatozoa with cytoplasmic droplets and abnormalities. As a general rule, the main motility parameters were not affected by the rearing diet nor the season.

\section{ACKNOWLEDGEMENTS}

The present work was supported by a grant from CICYT: AGF98-0470-C02-01.

\section{REFERENCES}

[1] Viudes de Castro MP, Vicente JS. Effect of sperm count on the fertility and prolificity rates of meat rabbits. Anim Reprod Sci 1997, 46: 313-319.

[2] Theau-Clément M, Michel N, Esparbíe J, Bolet G. Effects of artificial photoperiods on sexual behaviour and sperm output in the rabbit. Anim Sci 1995, 60: 143-149.

[3] Rebollar PG, Alvariño JMR. Efecto de un tratamiento continuado con gonadorelina y hCG sobre parámetros seminales de conejos jóvenes. ITEA 1997, 18 (II): 460-462.

[4] Mocé E, Lavara R, Lavara F, Vicente JS Effect of reproductive rhythm on seminal parameters from a rabbit line with high growth rate. Proc 7th World Rabbit Congress, Valencia 2000, Vol A, p 197-201.

[5] Papadomichelakis G, Fegeros K, XylouriFrangiadakie E, Papadopoulos G. Effects of dietary energy and protein content on libido and semen characteristics of bucks. Proc 7th World Rabbit Congress, Valencia 2000, Vol B, p 357-364.

[6] Luzi F, Maertens L, Mijten P, Pizzi F. Effect of feeding level and dietary protein content on libido and semen characteristics of bucks. Proc 6th World Rabbit Congress, Toulouse, 1996, Vol 2, p 87-92. 
[7] Scapinello C, Vanini de Moraes G, Rodrigues de Souza ML, Andreazzi MA, BianospinoAntunes E. Influência de diferentes níveis de metionina + cistina sobre a produçao de sêmen de celhos nova zelâmdia branco. Revista UNIMAR 1997, 19: 923-931.

[8] Nizza A, Di Meo C, Taranto S. Influence of dietary protein content on libido and semen characteristics of bucks. Proc 7th World Rabbit Congress, Valencia, 2000, Vol A, p 217224.

[9] El-Masry KA, Nasr AS, Kamal TH. Influences of season and dietary supplementation with selenium and vitamin E or Zinc on some blood constituents and semen quality of New Zealand White rabbit males. World Rabbit Sci 1994, 2: 79-86.

[10] Castellini C, Lattaiolo P, Bernardini M. Effect of dietary supplementation with $\alpha$-tocopheryl acetate and ascorbic acid on qualitative characteristics and fertilizing ability of rabbit semen. World Rabbit Sci 1999, 7: 217-220.

[11] Lavara R, Mocé E, Pascual JJ, Cervera C, Viudes de Castro MP, Vicente JS. Effects of environmental temperature and vitamin supplements on seminal parameters from a rabbit line selected by high growth rate. Proc 7 th World Rabbit Congress, Valencia, 2000, Vol A, p 167-171.

[12] Mocé E, Aroca M, Lavara R, Pascual JJ. Effect of dietary zinc and vitamin supplementation on semen characteristics of high growth rate males during summer season. Proc 7th World Rabbit Congress, Valencia, 2000, Vol A, p 203-209.

[13] Yousef MI, Abdallah GA, Kamel KI. Effect of ascorbic acid and Vitamin E supplementation on semen quality and biochemical parameters of male rabbits. Anim Reprod Sci 2003, 76: 99-111.

[14] Pascual JJ. Nutrición de machos destinados a inseminación artificial. II Jornadas Internacionais de Cunicultura, Vila Real, 2002, p $197-$ 212

[15] Pérez JM, Lebas F, Gidenne T, Maertens L, Xiccato G, Parigi-Bini R, Dalle Zotte A, Cossu ME, Carazzolo A, Villamide MJ, Carabaño R, Fraga MJ, Ramos MA, Cervera C, Blas E, Fernández-Carmona J, Falcao e Cunha L, Bengala Ferre J. European reference method for in vivo determination of diet digestibility in rabbits. World Rabbit Sci 1995, 3: 41-43.

[16] Association of Official Analytical Chemists. Official methods of analysis of the Association of Official Analytical Chemists, 16th edition. Association of Official Analytical Chemists, 1991, Washington, DC.

[17] Van Soest PJ, Robertson JB, Lewis BA Methods for dietary fiber, neutral detergent fiber and non starch polysaccharides in relation to animal nutrition. J Dairy Sci 1991, 74: 3583-3597.

[18] European Group on Rabbit Nutrition (EGRAN). Technical note: Attempts to harmonize chemical analyses of feeds and faeces for rabbit feed evaluation. World Rabbit Sci 2001, 9: 57-64.

[19] Estany J, Camacho J, Baselga M, Blasco A. Selection response of growth rate in rabbits for meat production. Genet Sel Evol 1992, 24: 527-537.

[20] Pascual JJ, Castellá F, Cervera C, Blas E, Fernández-Carmona J. The use of ultrasound measurement of perirenal fat thickness to estimate changes in body condition of young female rabbits. Anim Sci 2000, 70: 435-442.

[21] Pursel VG, Johnson LA. Glutaraldehyde fixation of boar spermatozoa for acrosome evaluation. Theriogenology 1974, 1: 63-68.

[22] Littell RC, Henry PR, Ammerman CB. Statistical analysis of repeated measures data using SAS procedures. J Anim Sci 1998, 76 : 1216-1231.

[23] Baselga M, Blasco A. Mejora genética del conejo de producción de carne. MundiPrensa, 1989, p 110

[24] Parigi-Bini R, Xiccato G. Energy Metabolism and Requirements. In: De Blas C, Wiseman J (Eds), The Nutrition of the Rabbit, CABI Publishing, 1998, p 103-132.

[25] Fraga MJ. Protein Requirements. In: De Blas C, Wiseman J (Eds), The Nutrition of the Rabbit, CABI Publishing, 1998, p 133-144.

[26] Pascual JJ, Cervera C, Fernández-Carmona J. Revisión de trabajos de investigación sobre cebo de conejos. Proc $2^{\circ}$ Congresso de Cunicultura de las Amaricas, La Habana, Cuba, 2002, p 130-132.

[27] Egea MD, Roy TJ. Análisis del semen de conejo para inseminación artificial. Resultados de fertilidad. Boletín de Cunicultura 1992, 59: 49-51

[28] Alvariño JMR. Reproductive performance of male rabbits. Proc 7th World Rabbit Congress, Valencia 2000, Vol A, p 13-35.

[29] Mocé E, Lavara R, Lavara F, Vicente JS. Effect of reproductive rhythm on seminal parameters from a rabbit line with high growth rate. Proc 7th World Rabbit Congress, Valencia 2000, Vol A, p 197-201. 
[30] Louis CF, Lewis AJ, Weldon WC, Ermer PM, Miller PS, Kittok RJ, Stroup WW. The effect of energy and protein intakes on boar libido, semen characteristics, and plasma hormone concentration. J Anim Sci 1994, 72: 2051-2060.

[31] Brown BW. A review of nutritional influences on reproduction in boars, bulls and rams. Reprod Nutr Dev 1994, 34: 89-114.

[32] Vicente JS, Viudes-de-Castro MP. A sucroseDMSO extender for freezing rabbit semen. Reprod Nutr Dev 1996, 36: 485-492.

[33] Barth AD, Oko RJ. Abnormal morphology of bovine spermatozoa. Iowa State University Press, 1989.

[34] Castellini C, Lattaioli P. Effect of number of motile sperms inseminated on reproductive performance of rabbit does. Anim Reprod Sci 1999, 57: 111-120.
[35] Roca J, Martínez S, Vázquez JM, Lucas X, Parrilla I, Martínez EA. Viability and fertility of rabbit spermatozoa diluted in Tris-buffer extenders and stored at $15{ }^{\circ} \mathrm{C}$. Anim Reprod Sci 2000, 64: 103-112.

[36] Castellini C, Lattaioli P, Moroni M, Minelli A. Effect of seminal plasma on the characteristics and fertility of rabbit spermatozoa. Anim Reprod Sci 2000, 63: 275-282.

[37] Viudes de Castro MP, Vicente JS, Lavara R. Effet du nombre de spermatozoïdes sur la fertilité de la semence conservée 24 heures chez le lapin. Ann Zootech 1999, 48: 407-412.

[38] Castellini C, Lattaioli P, Dal Bosco A, Beghelli D. Effect of supranutritional level of dietary $\alpha$-tocopheryl acetate and selenium on rabbit semen. Theriogenology 2002, 58: 1723-1732. 